\title{
PEMBERIAN ASI EFEKTIF MEMPERSINGKAT DURASI PEMBERIAN FOTOTERAPI
}

\author{
Rahmah $^{1,2 *}$, Krisna Yetti ${ }^{3}$, Besral $^{4}$ \\ 1. PSIK FKIK Universitas Muhammadiyah Yogyakarta Bagian Keperawatan Anak, Yogyakarta 55183, Indonesia \\ 2. Program Studi Magister Fakultas Ilmu Keperawatan Universitas Indonesia, Depok 16424, Indonesia \\ 3. Fakultas Ilmu Keperawatan Universitas Indonesia, Depok 16424, Indonesia \\ 4. Fakultas Kesehatan Masyarakat Universitas Indonesia, Depok 16424, Indonesia \\ *Email:dekrahma@yahoo.com
}

\begin{abstract}
Abstrak
Penelitian ini bertujuan untuk mengetahui perbedaan status hidrasi, perubahan nilai total serum bilirubin, dan perbedaan durasi fototerapi bayi yang mendapat fototerapi dengan diberi ASI dan susu formula Desain penelitian yang digunakan adalah deskriptif, observasional, dan prospektif terhadap 34 bayi cukup bulan yang sehat di sebuah rumah sakit di Jakarta. Responden dibagi ke dalam tiga kelompok, yaitu; kelompok bayi yang hanya diberi susu formula, kelompok bayi yang hanya diberi ASI, dan kelompok bayi yang diberi ASI dan susu formula. Hasil penelitian, menggunakan analisa data univariat dan bivariat dengan tes statistik Chi-square, ANOVA dan Mann-Whitney, menunjukkan bahwa tidak ada perbedaan status hidrasi dan perbedaan perubahan nilai total serum bilirubin ( $p=0,76 ; \alpha=0,05)$, tetapi ada perbedaan durasi fototerapi antara ke tiga kelompok $(p=0,001 ; \alpha=$ $0,05)$. Kelompok yang diberi ASI mempunyai durasi fototerapi tersingkat. Penelitian ini merekomendasikan agar perawat memastikan keefektifan breastfeeding selama fototerapi.
\end{abstract}

Kata kunci: bayi, fototerapi, ASI, formula, hidrasi, durasi terpapar

\begin{abstract}
This study aims to determine differences in hydration status, changes in value of total serum bilirubin, and the difference in duration of phototherapy newborns who received phototherapy with breast-fed and formula feeding. The study design used is descriptive, observational, and prospective to 34 healthy newborns at a hospital in Jakarta. Respondents were divided into three groups, there is group of newborns with formula feeding, group of newborns with breast-fed, and group of newborns with breast-fed and formula feeding. The results, using univariate and bivariate data analysis with statistical chi-square test, ANOVA, and Mann-Whitney, shows that there is no difference in hydration status and differences in changes in value of total serum bilirubin $(p=0.76 ; \alpha=0.05)$, but there are differences in the duration of phototherapy between to the three groups $(p=$ $0.001 ; \alpha=0.05)$. The group who were breastfeed has the shortest duration of phototherapy. This study recommends that nurses ensure the effectiveness of breastfeeding during phototherapy.
\end{abstract}

Keywords: newborn, phototherapy, breastfed, formula, hydration, duration of exposure

\section{Pendahuluan}

Hiperbilirubinemia merupakan masalah kesehatan pada bayi baru lahir yang disebabkan oleh akumulasi jumlah bilirubin yang berlebihan dalam darah. Kondisi ini ditandai dengan peningkatan total serum bilirubin dalam darah (di atas $5 \mathrm{mg} /$ dl), adanya jaundice atau ikterus yang merupakan warna kekuningan pada kulit, sklera, dan kuku (Porter \& Dennis, 2002; Hockenberry \& Wilson, 2007). Sebuah penelitian yang dilakukan di Rumah Sakit Umum Pusat Nasional Cipto Mangunkusumo selama tahun 2003 melaporkan bahwa 23,8\% dari 1509 bayi baru lahir yang dirawat memiliki kadar bilirubin di atas $13 \mathrm{mg} / \mathrm{dL}$, dan dari 128 (8,5\%) kematian bayi baru lahir, 24\% kematian terkait hiperbilirubinemia (Moeslichan, et al., 2004).

Fototerapi digunakan sebagai terapi pengobatan pada bayi baru lahir yang mengalami hiperbilirubinemia karena aman dan efektif untuk menurunkan bilirubin dalam darah (Potts \& Mandleco, 2007). Penelitian yang dilakukan oleh Kuzniewicz, Escobar, dan Newman (2009), yang menunjukkan bahwa peningkatan penggunaan fototerapi mampu menurunkan kejadian hiperbilirubinemia berat. 
Fototerapi dapat meningkatkan terjadinya kehilangan cairan dalam tubuh melalui insensible transepidermal lost dan melalui feses, serta perubahan motilitas pada saluran gastrointestinal (Metzger, et al., 2001; Berant, et al., 1983, dalam Iranpour, Nohekhan, \& Haghshenas, 2004). Hidrasi yang tidak adekuat dapat menyebabkan kurangnya efektivitas fototerapi, sehingga upaya untuk mempertahankan hidrasi yang adekuat sangat penting untuk meningkatkan efikasi fototerapi (American Academy of Pediatric, 2004; Iranpour, Nohekhan, \& Haghshenas, 2004; Maisels, 2008).

Pemenuhan kebutuhan cairan pada bayi untuk mempertahankan hidrasi yang adekuat dan mencegah terjadinya dehidrasi selama fototerapi merupakan tanggung jawab perawat (Hockenberry \& Wilson, 2007; Murray \& Rinney, 2007). Menurut Frerichs (1879) dalam Gourley (2000), yang menjelaskan bahwa perawatan yang buruk dapat berpengaruh buruk pada bayi baru lahir yang mengalami hiperbilirubinemia. Perawat melaksanakan asuhan keperawatan memiliki tujuan untuk mempertahankan status hidrasi pada bayi agar tetap dalam keadaan normal yakni dengan meningkatkan jumlah masukan cairan, yaitu berupa ASI dan atau susu formula selama periode fototerapi.

Penelitian yang dilakukan oleh Gulcan, Tiker, dan Kilicdag (2007) yang mencatat bahwa adanya kehilangan berat badan yang lebih besar dari berat badan lahir pada bayi yang disusui oleh ibunya selama fototerapi, hal ini diduga disebabkan karena rendahnya masukan cairan, rendahnya intake kalori atau peningkatan sirkulasi enterohepatik dari bilirubin pada bayi yang mendapatkan ASI (Gourley, 2000).

Penelitian ini bertujuan untuk mengetahui perbedaan status hidrasi, perubahan nilai total serum bilirubin, dan durasi fototerapi terhadap pemberian ASI, formula, dan ASI tambah formula terhadap bayi yang mendapatkan tindakan fototerapi di sebuah rumah sakit di Jakarta.

\section{Metode}

Penelitian ini merupakan penelitian deskriptif dengan menggunakan rancangan prospective. Pada penelitian ini subjek dibagi menjadi tiga kelompok yaitu kelompok bayi yang hanya diberi susu formula, kelompok bayi yang hanya diberi ASI, dan kelompok bayi yang diberi ASI dengan tambahan susu formula.

Teknik pengambilan sampel ini menggunakan non probability sampling yaitu consecutive sampling. Sampel diambil sesuai dengan kriteria inklusi yang telah ditetapkan. Penelitian ini dilakukan mulai Mei hingga Juni 2010.

Populasi penelitian ini adalah seluruh bayi cukup bulan yang difototerapi di sebuah rumah sakit (RS) di Jakarta dengan kriteria inklusi pada sampel adalah bayi sehat cukup bulan, usia gestasi mulai dari 37 minggu hingga kurang dari 42 minggu, sehat tanpa penyakit penyerta, orangtua responden memberikan persetujuan, dan dirawat di RS tersebut. Kriteria eksklusi adalah bayi mendapat cairan melalui intravena dan mendapat transfusi tukar.

Subjek dengan jenis pemberian minum yang berbeda diamati dan diikuti selama periode fototerapi terhadap status hidrasinya, perubahan nilai total serum bilirubin serta durasi fototerapi. Status hidrasi diketahui dengan mengamati perubahan berat badan yang terjadi selama periode fototerapi sebagai indikator penilaian kecukupan jumlah masukan cairan dengan berbagai cara pemberian dan jumlah cairan yang keluar melalui urin serta kejadian muntah.

Penelitian ini dilakukan di sebuah rumah sakit di Jakarta. Oleh karena itu, perlu melihat gambaran kondisi di unit perinatologi sebuah rumah sakit di Jakarta, selama dalam proses pengambilan data, semua pasien menggunakan alat fototerapi dengan jenis yang sama yakni lampu fluorescent (Philips TL 20W/ 52, Philips Lighting, The Netherlands) dengan jarak $40 \mathrm{~cm}$ dari box bayi dengan kondisi mata tertutup dan menggunakan diapers. 
Suhu ruangan antara $26-28^{\circ} \mathrm{C}$. Fototerapi dilakukan terus menerus kecuali dihentikan saat pemberian cairan/ minum, mandi, dan intervensi keperawatan lain.

Data hasil penelitian ini dianalisis menggunakan analisis univariat dan bivariat dengan satu program komputer. Analisis univariat dilakukan pada variabel karakteristik responden (usia, berat badan, dan nilai total serum bilirubin), perubahan berat badan harian, cara pemberian minum, kejadian muntah, volume pengeluaran urin, dan selisih perubahan nilai total serum bilirubin responden. Analisis bivariat yang digunakan adalah analisis chi-square, ANOVA, dan MannWhitney test.

Grafik 1. Perbedaan Status Hidrasi pada Bayi yang Difototerapi

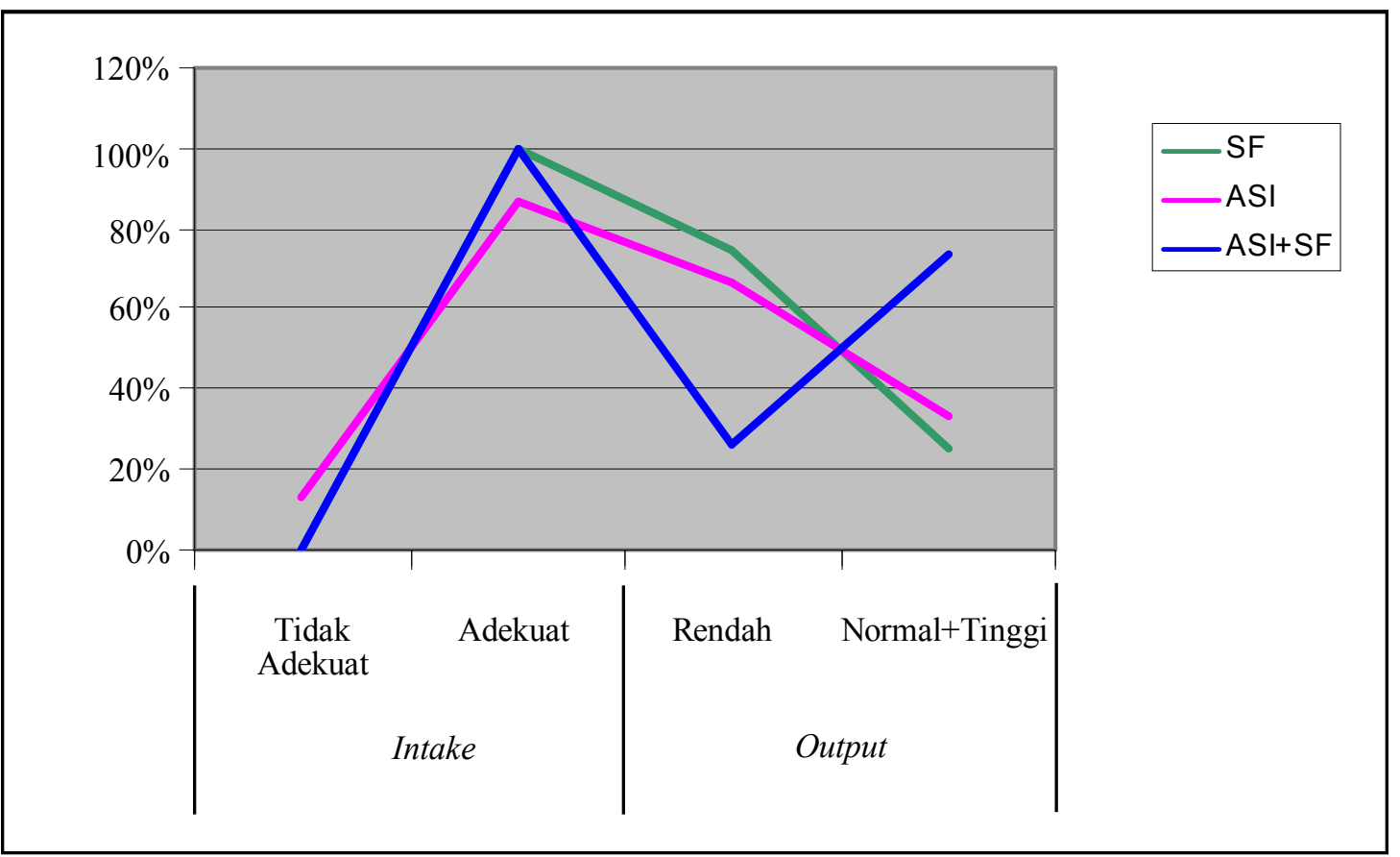

\section{Hasil}

Penelitian ini membuktikan dan menjawab pertanyaan penelitian yang diajukan bahwa apakah ada perbedaan status hidrasi perubahan nilai total serum bilirubin dan durasi fototerapi pada bayi dengan jenis pemberian minum yang berbeda. Berdasarkan hasil penelitian ini didapatkan data bahwa tidak terdapat perbedaan status hidrasi pada ketiga kelompok bayi dengan jenis pemberian minum yang berbeda.

Meskipun demikian, didapati 100\% responden pada kelompok bayi yang diberi ASI dengan tambahan susu formula berada dalam kategori masukan cairan adekuat dan 73,3\% dengan volume pengeluaran urin normal dan tinggi. Hal ini dapat dilihat dalam grafik 1.

Hasil analisis data yang diperoleh dengan menggunakan uji ANOVA menggambarkan tentang rerata persentase penurunan nilai total serum bilirubin per jam (\% per jam) pada ketiga kelompok jenis pemberian minum. Berdasarkan hasil analisis tersebut maka dapat dilihat bahwa tidak ada perbedaan rerata persentase penurunan nilai total serum bilirubin per jam (\% per jam) pada bayi dengan jenis pemberian minum yang berbeda $(p=0,76 ; \alpha=0,05)$. Hal tersebut terlihat dalam grafik 2 . 
Pada tabel 1 menggambarkan tentang durasi fototerapi pada kelompok jenis pemberian minum. Berdasarkan hasil analisis tersebut maka terlihat bahwa bayi yang mendapatkan ASI dengan tambahan susu formula memiliki durasi fototerapi yang lebih lama dibandingkan dengan kelompok bayi yang hanya diberikan ASI selama fototerapi $(\mathrm{p}=0,001 ; \alpha=0,05)$.

\section{Pembahasan}

\section{Penilaian Status Hidrasi}

\section{Penilaian masukan cairan berdasarkan per- ubahan berat badan}

Protokol Asuhan Neonatal (2008) menjelaskan bahwa salah satu parameter untuk menilai status hidrasi dan kecukupan masukan cairan pada neonatus adalah berat badan, sehingga diberikan batasan bila neonatus kehilangan berat badan melebihi 3\% perawat harus mengevaluasi keefektifan pemberian (intake) cairan pada bayi baru lahir untuk mempertahankan hidrasi yang adekuat.

Hasil penelitian ini menunjukan bahwa terjadi penurunan berat badan selama fototerapi pada $66,7 \%$ bayi dari kelompok yang hanya diberikan ASI dengan rerata presentase penurunan berat badan harian sebesar 1,7\% dari berat badan saat mulai fototerapi dengan standar deviasi sebesar $1,2 \%$, sehingga sebesar $6,7 \%$ responden pada kelompok bayi yang hanya diberi ASI selama fototerapi berada dalam status masukan cairan tidak adekuat.

Penelitian yang dilakukan oleh Kusuma, et al. (2009) juga menunjukkan terjadinya penurunan berat badan pada bayi baru lahir pada minggu pertama kehidupan yang hanya disusui oleh ibu yakni sejumlah $18,3 \%$ dan $17,9 \%$ pada bayi yang disusui oleh ibu dan mendapat tambahan susu formula. Penurunan berat badan ini salah satunya dipengaruhi oleh paparan fototerapi.

Grafik 2. Rerata Persentase Penurunan Nilai Total Serum Bilirubin (\% per jam) pada Bayi yang Difototerapi

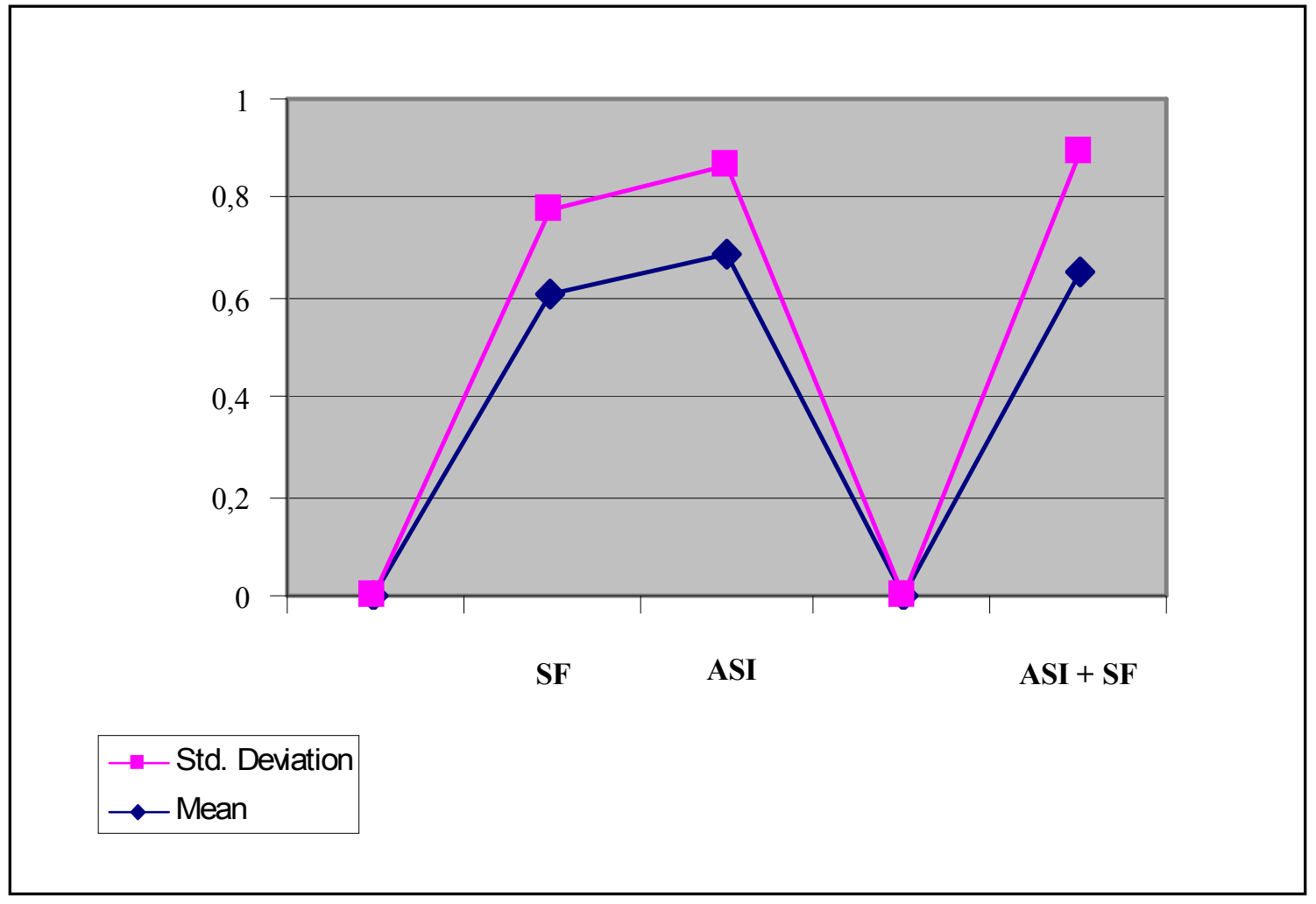


Penelitian lain yang mendukung penelitian ini adalah penelitian yang dilakukan oleh Gulcan, Tiker, dan Kilicdag (2007) yang mengungkapkan bahwa terjadi penurunan berat badan lahir yang lebih besar lahir pada bayi yang diberikan ASI (8,1\% dengan standar deviasi sebesar 3,9\%), dibandingkan dengan bayi yang diberikan ASI dengan tambahan susu formula $(5,4 \%$ dengan standar deviasi sebesar 2,6\%). Perubahan yang cepat dari berat badan menggambarkan perubahan cairan tubuh. Berat badan diperlukan untuk menentukan banyaknya cairan pengganti yang dibutuhkan (Kushartono, 2006).

Menurut Bhat, Lewis, dan Dinakar (2001), yang menyatakan bahwa perawat seharusnya mengevaluasi berat badan bayi setiap hari untuk menilai keadekuatan breast-feeding. Keadekuatan pemberian breast-feeding menjadi tantangan tersendiri bagi perawat dalam memenuhi kebutuhan cairan pada bayi yang difototerapi. Hal ini disebabkan karena bayi dengan hyperbilirubinemia biasanya malas minum sehingga jika tidak diperhatikan dengan baik dapat menyebabkan kurangnya masukan cairan dari yang dibutuhkan oleh bayi.

\section{Volume Pengeluaran Urin}

Volume pengeluaran urin dapat digunakan untuk memperkirakan kehilangan cairan tubuh. Volume pengeluaran urin normal pada bayi adalah 2-3 ml/ kgBB/ jam (Murray \& McKinney, 2007; Wong \& Hockenberry, 2007; Indrasanto, et al., 2008). Akan tetapi, bayi baru lahir memiliki keterbatasan untuk meningkatkan volume urin karena terkait dengan fungsi ginjal yang belum sempurna.

Hasil penelitian ini menunjukkan bahwa rerata volume pengeluaran urin pada bayi yang hanya diberi ASI sebesar $1,77 \mathrm{ml} / \mathrm{kg} / \mathrm{jam}$, sedangkan pada bayi yang diberi susu formula dan bayi yang diberi ASI dengan tambahan susu formula selama fototerapi menunjukkan bahwa rerata volume pengeluaran urin sebesar 2,02 ml/kg/jam dan 2,47 $\mathrm{ml} / \mathrm{kg} /$ jam.
Fungsi ginjal untuk mengeluarkan urin yang bersifat wajib, guna untuk mempertahankan homeostasis tubuh. Pengeluaran urin diatur oleh mekanisme yang saling melengkapi, sehingga pengeluaran urin dengan ketat mengatur volume dan komposisi cairan ekstraseluler. Bila masukan cairan dalam tubuh berkurang, maka volume pengeluaran urin akan menurun (Nelson, et al., 2005). Penilaian volume pengeluaran urin ini dapat digunakan untuk menilai keefektifan masukan cairan pada bayi. Pada keadaan kurang masukan cairan, tubuh akan berespon secara bertahap sehingga memungkinkan volume urin terus menerus diatur.

Hasil penelitian ini menunjukkan bahwa tidak ada perbedaan status hidrasi pada ketiga kelompok bayi dengan jenis pemberian minum yang berbeda secara statistik. Berdasarkan masukan (intake) cairan, didapati $66,7 \%$ bayi yang hanya diberi ASI selama fototerapi mengalami penurunan berat badan selama fototerapi. Sedangkan pengeluaran (output) cairan pada ketiga kelompok bayi dengan jenis pemberian cairan.

Meskipun secara frekuensi terlihat jumlah yang bermakna antara tingkat volume pengeluaran urin pada ketiga kelompok. Hal ini dapat disebabkan karena terlalu sedikitnya jumlah sampel dalam kelompok yang hanya diberikan susu formula yakni hanya 4 (empat) orang. Oleh karena itu, secara statistik hasil yang didapatkan tidak terlihat perbedaannya dan kurang dapat digeneralisasikan.

Kebutuhan cairan pada bayi cukup bulan dan bayi sehat sebesar 40 sampai $60 \mathrm{ml} / \mathrm{kgBB} /$ hari pada 2 (dua) hari pertama kehidupan, selanjutnya meningkat hingga 100 sampai $150 \mathrm{ml} / \mathrm{kg}$ BB/ hari (Murray \& McKinney, 2007). Cairan ini biasanya diperoleh dari ASI atau dari susu formula yang dibuat dengan benar. Bayi yang meminum cairan sesuai dengan jumlah yang dibutuhkan akan mengeluarkan urin sebesar kirakira 100ml dalam 24 jam (Bobak, Lowdermilk, \& Jensen, 2005). 
Pada bayi yang mendapat fototerapi, kebutuhan cairan ini akan meningkat. Dengan demikian, kebutuhan cairan bayi yang hanya diberi ASI selama fototerapi akan terpenuhi jika proses laktasi terlaksana dengan baik. Ibu yang walaupun mampu memproduksi lebih banyak ASI daripada kebutuhan bayinya, belum tentu dapat memenuhi kebutuhan cairan bayinya jika cara menyusuinya kurang efektif.
Ada banyak penyebab mengapa menyusui kurang efektif, yaitu karena kurang dukungan pada ibu dan kelemahan bayi dalam mengisap (Nelson, et al., 2005). Penelitian yang dilakukan oleh Dewey, et al. (2003) menunjukkan bahwa kurangnya masukan cairan pada bayi yang menyusu secara eksklusif disebabkan oleh $24 \%$ karena volume produksi ASI tidak adekuat dan 76\% karena teknik menyusui yang kurang baik.

Tabel 1.Perbedaan Durasi Fototerapi pada Bayi yang Difototerapi

\begin{tabular}{lccc}
\hline \multirow{2}{*}{ Jenis Pemberian Cairan } & \multicolumn{3}{c}{ Durasi fototerapi } \\
\cline { 2 - 4 } & Mean & SD & p \\
\hline SF $(\mathrm{n}=4)$ & 42 & 12 & 0,001 \\
ASI $(\mathrm{n}=15)$ & 44,8 & 17,8 & \\
ASI+SF $(\mathrm{n}=15)$ & 62,5 & 21,4 \\
\hline
\end{tabular}

Penelitian yang dilakukan Tan (1998) (dalam Iranpour, Nohekhan, \& Haghshenas, 2004) menunjukkan bahwa hasil yang berbeda. Bayi yang disusui sesuai dengan keinginan dan kebutuhan bayi selama fototerapi mengalami peningkatan masukan cairan sebesar 20 sampai $40 \%$.

American Academy of Pediatrics Work group On Breastfeeding (1997) memberikan rekomendasi pada kasus-kasus ineffective breastfeeding atau dehidrasi ringan, bahwa sebaiknya perawat membantu ibu untuk memerah ASI. Selain itu, rumah sakit juga sebaiknya menyediakan ruang khusus untuk ibu selama bayinya dirawat di rumah sakit.

Menurut Nelson, et al. (2005), yang menjelaskan bahwa memerah ASI biasanya akan menambah produksi susu dan memastikan persediaan yang cukup, untuk penggunaan ketika ibu tidak ada ataupun memberikan kesempatan pada ibu untuk beristirahat. Selain itu pula, ASI yang diperah dapat diberi dengan menggunakan sendok atau gelas sehingga dapat meminimalkan energi yang dikeluarkan oleh bayi karena proses mengisap memerlukan energi yang lebih besar.

\section{Durasi Fototerapi}

American Academy of Pediatrics clinical Practice Guideline Subcomité on Hyperbilirubinemia (2004) tidak memberikan ketentuan mengenai berapa lama durasi fototerapi yang efektif dalam menurunkan total serum bilirubin. Lamanya durasi fototerapi salahsatunya ditentukan oleh nilai total serum bilirubin saat mulai fototerapi dan fototerapi dihentikan jika nilai total serum bilirubin mencapai nilai kurang dari $12 \mathrm{mg} / \mathrm{dl}$ (Moeslichan, et al., 2004).

Hasil penelitian ini menunjukkan bahwa ada perbedaan durasi fototerapi yang bermakna antara bayi yang diberikan ASI dengan tambahan susu formula dengan bayi yang hanya diberikan ASI atau hanya diberi susu formula selama fototerapi. Adapun rerata durasi fototerapi pada kelompok SF (susu formula) adalah 42 jam dengan standar deviasi yaitu 12 jam, pada kelompok ASI adalah 44,8 jam dengan standar deviasi yaitu 17,8 jam. 
Sedangkan pada kelompok ASI dengan SF (susu formula) rerata durasi fototerapi adalah 62,5 jam dengan standar deviasi 21,4 jam. Dengan singkat dapat dikatakan bahwa pemberian ASI dapat mempersingkat durasi pemberian fototerapi pada bayi.

Hasil penelitian ini mematahkan penelitian yang dilakukan oleh Tan (1998), yang menunjukkan bahwa durasi fototerapi lebih lama pada kelompok bayi yang hanya diberi ASI selama fototerapi dengan rerata durasi fototerapi sebesar 64,5 jam dibandingkan dengan kelompok bayi yang diberi ASI dengan tambahan susu formula dengan rerata durasi fototerapi x 0020 f.a43, 3rubgf3y9bf rueb4rbv3z sebesar 54,9 jam.

Hasil yang berbeda pada penelitian ini karena ada perbedaan nilai total serum bilirubin saat mulai fototerapi dan selisih penurunan yang lebih besar antara nilai total serum bilirubin saat mulai fototerapi dengan nilai total serum bilirubin akhir pada kelompok bayi yang diberikan ASI dengan tambahan susu formula dibandingkan dengan yang hanya diberi ASI.

Namun, hasil penelitian juga menemukan bahwa tidak ada perbedaan persentase penurunan nilai total serum bilirubin tiap jamnya. Sehingga durasi fototerapi yang diperlukan lebih lama pada kelompok bayi yang diberi ASI dengan tambahan susu formula.

\section{Kesimpulan}

Hasil penelitian ini menunjukkan bahwa tidak terdapat perbedaan status hidrasi dan persentase penurunan nilai total serum bilirubin. Akan tetapi durasi fototerapi pada bayi yang diberi ASI lebih singkat daripada yang diberikan tambahan susu formula. Hasil penelitian ini memacu perawat untuk memastikan pemberian ASI yang efektif selama fototerapi, dengan melakukan pengkajian dan intervensi yang tepat terhadap posisi dan melekatnya bayi pada ibu (WK, NN, $\mathrm{KN}$ ).

\section{Referensi}

American Academy of Pediatrics Work Group on Breast-feeding. (1997). Breastfeeding and the use of human milk. Pediatrics, 100, 10351039.

American Academy of Pediatrics. (2004). Management of hyperbilirubinemia in the newborn infant 35 or more weeks of gestation. Diperoleh dari http://www.aappublication.org.

Bhat, S.R., Lewis, P., \& Dinakar, C. (2001). Case Report: Hypernatremics dehydration. Indian Pediatrics Journal, 38, 1174-1177.

Bobak, I.M., Lowdermilk, D.L., \& Jensen, M.D. (2005). Buku ajar keperawatan maternitas (Alih bahasa: Wijayarini MA., \& Anugrah, PI). Jakarta: Penerbit Buku Kedokteran EGC.

Gourley, G.R. (2000) Breastfeeding, diet, and neonatal hyperbilirubinemia. NeoReviews 1 (2), 2529.

Gulcan, H., Tiker, F., \& Kilicdag, H. (2007). Effect of feeding type on the efficacy of phototherapy. Indian Pediatrics Journal, 44, 32-36.

Hockenberry, M.N., \& Wilson, A., (2007). Essentials of pediatric nursing. St. Louis: Mosby Elsevier.

Indrasanto, E., Dharmasetiawani, N., Rohsiswanto, R., \& Kaban, R.K. (2008). Paket Pelatihan Pelayanan Obstetri dan Neonatal Emergensi Komprehensif (PONEK): Asuhan neonatal esensial. Jakarta: Penerbit Jaringan Nasional Pelatihan Klinis-Kesehatan Reproduksi (JNPKKR).

Iranpour, R., Nohekhan, R., \& Haghsenas. I. (2004). Effect of intravenous fluid supplementation on serum bilirubin level in jaundiced healthy neonates during conventional phototherapy. Journal of Research in Medical Sciences, 4, 186-190.

Kushartono. H., (2006). Terapi cairan dan elektrolit pada anak. Surabaya: Open Urika Creative Multimedia and Presentation Division. 
Kusuma, S., Agrawal, S.K., Kumar.P., Narang. A., Prasad.R. (2009). Hydration status of exclusively and partially breastfed near-term newborns in the first week of life. Journal Human Lactation, 25 (3), 280-286.

Kuzniewicz, M.W., Escobar, G.J., \& Newman, T.B. (2009). Impact of universal bilirubin screening on severe hyperbilirubinemia and phototherapy use. Pediatrics, 124 (4), 1031 1039.

Maisels, M.J., \& McDonagh,, A.F. (2008). Phototherapy for neonatal jaundice. NEJM, 358, 920-928.

Metzger, A.M., Yosipovitch, G., Hadad, E., \& Sirota, L. (2001). Transepidermal water loss and skin hydration in preterm infants during phototherapy. Amer J Perinatol, 18 (7), 393396.
Moeslichan, Surjono, A., Suradi, R., Rahardjani, K.B., Usman, A., Rinawati, et al. (2004). Tatalaksana ikterus neonatorum. Diperoleh dari http://www.yanmedikdepkes.net/

Murray, S.S., \& McKinney, S.A., (2007). Foundation of maternal-newborn nursing (4th Ed.). Singapore: Elsevier.

Nelson, W.E., Behrman, R.E., Kliegman, R., Arvin, A.M., (2005). Ilmu kesehatan anak (Alih bahasa: Wahab, AS). Jakarta: Penerbit Buku Kedokteran EGC.

Porter, M.L., \& Dennis, B.L., (2002). Hyperbilirubinemia in the term newborn. Am Fam Physician, 65 (4), 599-606. 